\title{
GENETIC VARIATION OF Tor tambroides (Bleeker, 1854) ALONG BATANG TARUSAN RIVER, WEST SUMATERA: IMPLICATIONS FOR STOCK IDENTIFICATION
}

\author{
Arif Wibowo and Siswanta Kaban \\ Institute for Inland Fisheries, Mariana, Palembang 30763, Indonesia \\ Received; April 08-2014 Received in revised from November 27-2015; Accepted December 06-2015 \\ email: wibarf@yahoo.com
}

\begin{abstract}
Mahseer (Tor tambroides, Bleeker, 1854) is an important consumption fish species in the Batang Tarusan River, located in the West Sumatera, Indonesia. In this study the CO1 of mtDNA sequence data were used to investigate genetic variability within and between populations of mahseer. Twenty four tissue samples were collected for genetic analysis in the Batang Tarusan River. Genetic analysis revealed two different haplotypes were existed. The overall nucleotide and haplotype variability were low in all sampling sites. Hierarchical AMOVA analysis showed that mahseer populations form a single panmictic population with low FST $=0.02794 ; p=0.418$ and high gene flow among population sampling. Corroborated result by genetic analysis; there is a strong argument suggesting that the populations could be treated as a single stock unit.
\end{abstract}

\section{KEYWORDS: Tor tambroides, mitochondrial DNA CO1, stock, Batang Tarusan River}

\section{INTRODUCTION}

The cyprinid fishes of the mahseer are endemic to Asia with natural distribution encompassing the transHimalayan region in the northwest to Sumatra and Borneo islands in the southeast, across a number of countries such as Nepal, Pakistan, India, Sri Lanka, Myanmar, China, Thailand, Laos, Cambodia, Vietnam, Indonesia and Malaysia. These species are largescaled barbells that live in upstream, clear, running waters (Shrestha, 1990; $\mathrm{Ng}, 2004)$. They are attractive as sport fish ( $\mathrm{Ng}, 2004)$, and are of great economical value and conservation concern (Nguyen et al., 2006), as well as of aquaculture potential (Ingram et al., 2005).

Although currently not listed by the IUCN as a protected or endangered species, the drastic decline in natural populations of mahseer has increased awareness among relevant authorities (e.g Fisheries Department, Indonesia and policy makers) of the importance of the conservation and proper management of this species. The proper management of fishery resources can be greatly enhanced by understanding the stock structure of wild populations. Information on the stocks is needed to meet objectives of fisheries management to achieve sustainable yield, avoid recruitment failures, rebuild overfished stocks, as well as to conserve threatened and endangered species. With growing acceptance of the need to conserve biodiversity, apply a precautionary approach, and operationally the ecosystem approach which places greater emphasis on spatial distributions and place-based management.
Therefore, in order to make inferences on stock identity, in this study, the mitochondrial cytochrome oxidase subunit I (COI) gene region was used to identify the stock structure of mahseer. Mitochondrial DNA (mtDNA) analysis has been successfully used as a molecular marker for species identification and for determination of population genetic structure in a wide variety of fish taxa (see reviews by Ovenden, 1990; Billington and Hebert, 1991; Meyer, 1993). MtDNA gives a better estimate of genetic differentiation than nuclear markers since it is approximately fourfold more sensitive (Birky et al., 1983).

The goals of the study were to (i) survey the genetic variation and structure of the mahseer populations in the rivers of Batang Tarusan, (ii) to test the hypothesis that mahseer populations in this region form a single stock unit. (iii) to define species boundaries in Batang Tarusan mahseer using COI mtDNA sequences, testing the reliability of the presence of the median lobe as an indicator of valid species.

\section{MATERIALS AND METHODS}

Sample Description and Collection Locations

Mahseer were sampled during 2012, fin clips from individuals were collected for DNA analysis during different field surveys. A total of 24 individuals from the Batang Tarusan River were sampled and the tissues were kept in 95\% ethanol until extraction (Table 1 and Fig. 1).

DNA was extracted from soft tissues using the Extraction Kit procedure 'DNeasy Blood \& Tissue' 
(Geneaid). Partial fragments of the mitochondrial gene Cytochrome Oxidase Subunit I were amplified using universal primers described by Ivanova et al. (2007):

Fish-COI-F (5'-ACT TCAAAC TTC CAY AAA GAY aty GG-3) and COI-Fish-R (5'-TAG ACT TCT GGG TGG CCR AAR Aay CA-3').

Table 1. Summary of Tor tambroides (Bleeker, 1854), genetic samples, sampling localities and georeferences for mahseer collected from Batang Tarusan River

\begin{tabular}{cclcc}
\hline No & Genetic samples (ind) & Locality & Latitude & Longitude \\
\hline 1 & 8 & Sungai Lundang & $01^{\circ} 07.447^{\prime} \mathrm{S}$ & $100^{\circ} 29.351^{\prime} \mathrm{E}$ \\
2 & 9 & Kuto Tarusan & $01^{\circ} 08.111^{\prime} \mathrm{S}$ & $100^{\circ} 29.371^{\prime} \mathrm{E}$ \\
3 & 7 & Ps. Minggu & $01^{\circ} 06.8116^{\prime} \mathrm{S}$ & $100^{\circ} 29.081^{\prime} \mathrm{E}$ \\
Total & 24 & & & \\
\hline
\end{tabular}

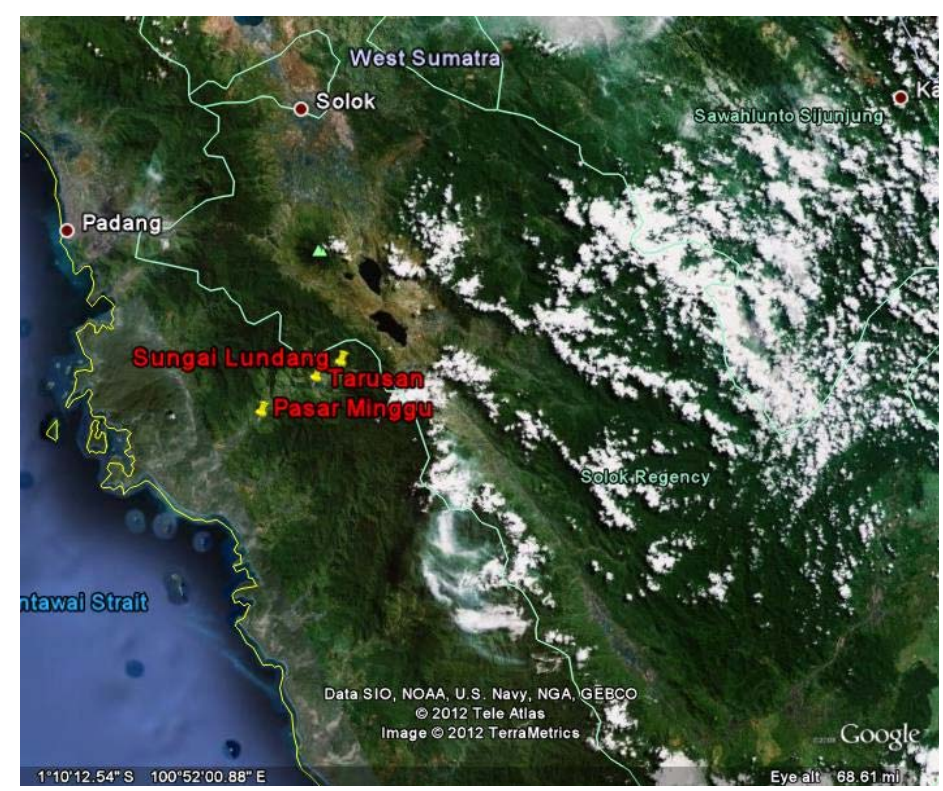

Figure 1. Map showing the relative locations of sampling sites of the Batang Tarusan River.

PCR cycling parameters included an initial denaturation phase at $95^{\circ} \mathrm{C}$ for $10 \mathrm{~min}$, followed by 35 cycles at $94^{\circ} \mathrm{C}$ for $1 \mathrm{~min}, 48^{\circ} \mathrm{C}$ for $1 \mathrm{~min}$ and $72^{\circ} \mathrm{C}$ for $1.5 \mathrm{~min}$ and ended with a final extension at $72^{\circ} \mathrm{C}$ for 7 min. Finally, all amplicons were automatically sequenced in both directions at First Base, Singapore (www.firstbase.com), and these sequences were subject to register in Genbank (NCBI), the accession numbers are KC905001 - KC905024.

$\mathrm{COl}$ sequences were edited with BioEdit (version 7.0.4.1) (Hall, 1999) and multiple alignments were done using Clustal W (Thompson et al., 1997). Following alignments, $\mathrm{COl}$ sequences were translated to amino acids to check for the presence of premature stop codons that indicate the presence of nuclear pseudo genes or sequencing errors. Sequence divergence was estimated using the Kimura two parameters (K2P) model of base substitution (Kimura,
Polymerase chain reaction (PCR) amplifications were made in a $50 \mu \mathrm{L}$ of reaction volume consisted of $5 \mu \mathrm{L}$ DNA samples, $16 \mu \mathrm{L}$ double distillate water, $2 \mu \mathrm{L}$ of each primer and $25 \mu \mathrm{L}$ of $\mathrm{PCR}$ ready mixture solution (KAPPA). 
geographic proximity as well as the river basin to which they belong and the data implemented in Arlequin, version 3.1 (Excoffier et al., 2005).

\section{RESULTS AND DISCUSSION Results}

Averages of 703 base pairs (bp) (Fig. 2) of the mtDNA CO1 in 25 mahseer were sequenced (GenBank
Accession numbers from KC905001 to KC905024). Six polymorphic nucleotide sites were observed from which all were parsimony-informative. There were only 1 site with transition-type and 5 with transversiontype mutations (Fig. 3 \& Tab. 2). The average nucleotide frequencies were: $A=27.1 \%, T=28.3 .5 \%$, $\mathrm{C}=27.3 \%$ and $\mathrm{G}=17.3 \%$ (Fig. 3 ).

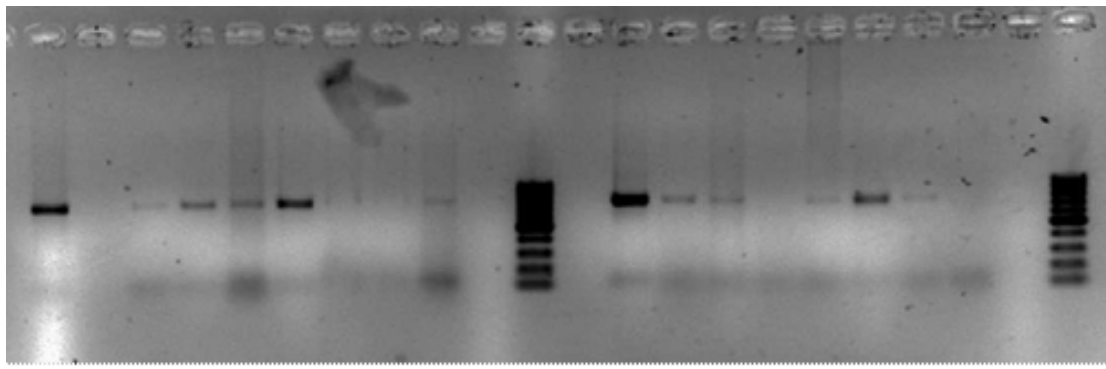

Figure 2. COI gene amplicon of Tor tambroides using primer pairs COI F/COI R.

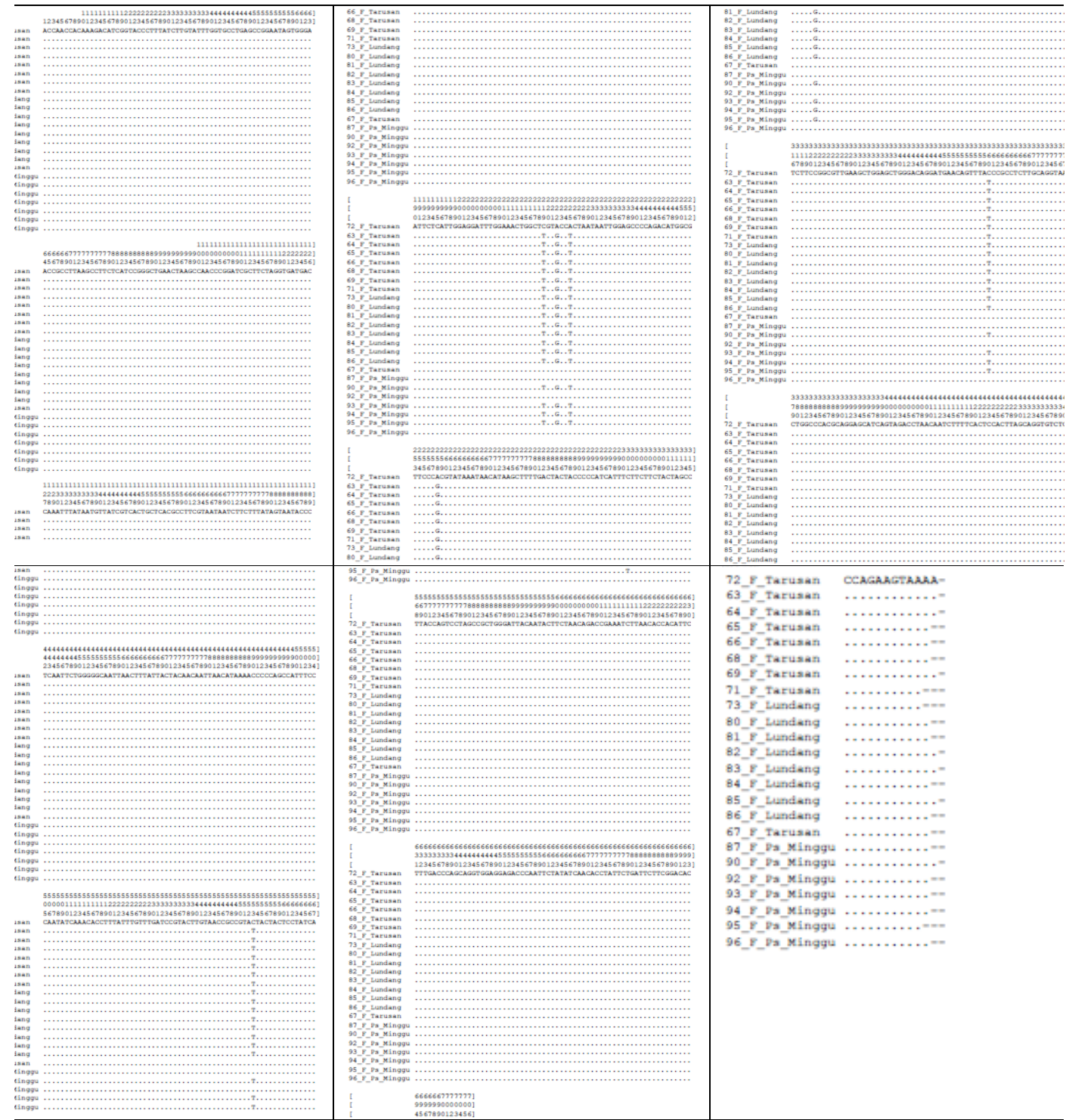

Figure 3. $703 \mathrm{pb} \mathrm{COI}$ sequences of Tor tambroides. 
From the 2 haplotypes, 1 is found among all populations, and 2 is restricted to two populations; Tarusan dan Pasar Minggu. Haplotype 1 was the most common, accounting for over $79.16 \%$ of the haplotypes identified from all sampled locations. The genetic variability within each sampled population was expressed as haplotype diversity $(\mathrm{Hd})$ and nucleotide diversity (ð) indices, where as the overall genetic and nucleotide variability population sampled were low, (Table 3).

Table 2. Particular haplotypes and nucleotide sites $\mathrm{COI}$ sequence from three location-specific samples of Tor tambroides

\begin{tabular}{lccccccccccc}
\hline Type & & \multicolumn{4}{c}{ Nucleotide } & & & $\begin{array}{c}\Sigma \\
\text { Tarusan }\end{array}$ & $\begin{array}{c}\Sigma \\
\text { Lundang }\end{array}$ & $\begin{array}{c}\sum \text { Pasar } \\
\text { Minggu }\end{array}$ & Total \\
& 5779 & 5782 & 5784 & 5818 & 5920 & 6113 & & & & \\
\hline Haplotype 1 & T & G & T & G & C & T & 7 & 8 & 4 & 19 \\
Haplotype 2 & C & A & A & A & T & C & 2 & 0 & 3 & 5 \\
& & & & & & & & & & 24 \\
\hline
\end{tabular}

Table 3. Sampling location and descriptive statistic of mahseer populations

\begin{tabular}{lcccc}
\hline Sampling location & $\mathrm{N}$ & No. haplo & $\mathrm{Hd} \pm$ s.d & $\pi \pm$ s.d \\
\hline Sungai Lundang & 8 & 1 & $0.00 \pm 0.00$ & $0.00 \pm 0.00$ \\
Tarusan & 9 & 2 & $0.389 \pm 0.164$ & $0.003 \pm 0.02$ \\
Ps. Minggu & 7 & 2 & $0.4762 \pm 0.171$ & $0.004 \pm 0.003$
\end{tabular}

The haplotypes (also from two morphotype, with the presence and absence of median lobe) seem to be randomly distributed from the different sampled sites. It can be observed by the random way that the haplotypes are allocated on the unrooted neighborjoining tree (Fig. 4). Hierarchical AMOVA analysis revealed that the greatest genetic variation is found within the sampled population. No genetic differentiation was found either among groups (Tab. 4). When the samples were analyzed as one AMOVA group, i.e., each sample as a population, again, no genetic structure was observed (FST $=0.02794 ; p=$ 0.418). Pairwise comparison of FST (Tab. 5) showed no significant differences between all sampled populations.

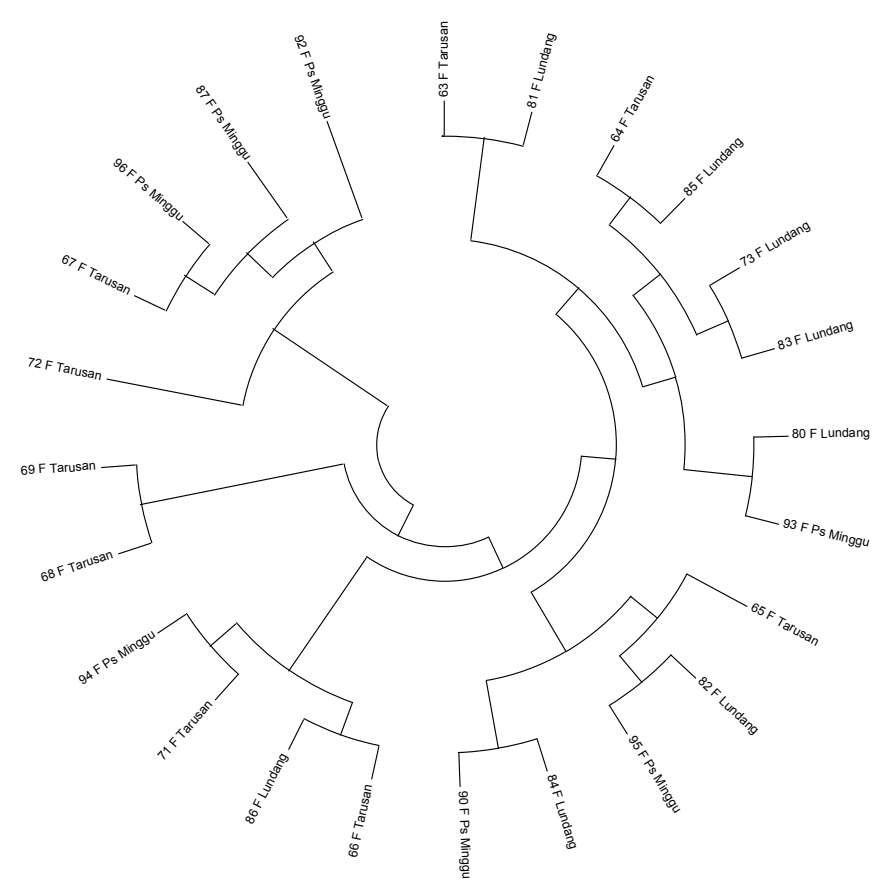

Figure 4. Neighbor-joining tree estimated from Kimura-two-parameter distance among the 24 mtDNA CO1 haplotypes of mahseer populations. 
Table 4. Hierarchical AMOVA analysis on CO1 partial sequence data of mahseer populations according to their geographical location.

\begin{tabular}{lcccc}
\hline Source of variation & d.f & $\begin{array}{c}\text { Sum of } \\
\text { squares }\end{array}$ & $\begin{array}{c}\text { Variance } \\
\text { components }\end{array}$ & $\begin{array}{c}\text { Percentage of } \\
\text { variation }\end{array}$ \\
\hline Among populations & 2 & 2.095 & $0.02450 \mathrm{Va}$ & 2.79 \\
Within population & 21 & 17.905 & $0.85261 \mathrm{Vb}$ & 97.21 \\
Total & 23 & 18.353 & & \\
\hline
\end{tabular}

Fst $=0.02794, p$-Value $=0.418$

Table 5. Significant differences (significance level $=0.0500,110$ permutation test) of mahseer populations according to their geographical location.

\begin{tabular}{lccc}
\hline & Sungai Lundang & Tarusan & ps. Minggu \\
\hline Sungai Lundang & & - & - \\
Tarusan & - & & - \\
Pasar. Minggu & - & - & \\
\hline - non significant & &
\end{tabular}

\section{Discussion}

Tor tambroides has been described in the literature as a species presenting a low variability genetically (e.g. Nguyen et al., 2006; Esa et al., 2008). The occurrence of only two haplotypes in Batang tarusan population might be explained by 3 possibilities, but these could not be confirmed based on the present study alone. First, habitat destruction and overexploitation in the upper reaches/headwaters, might have resulted in a mass reduction in the effective population size (female parental stock) of $T$. tambroides ini the area that led to large reduction in mtDNA variations. Second, T. tambroides sample from Batang tarusan River might have originated from a single female parent, thus sharing common haplotype, since mtDNA is maternally inherited (Avise, 1987). Third the limited number of samples $(n=24)$ analyzed might have underestimated the actual mtDNA variations harboured by Batang tarusan River.

This study found that Tor tambroides populations have to lack genetic differentiation. The absence of a genetic structure among Tor tambroides populations can be explained by the ecological characteristics of Batang Tarusan River and the reproductive pattern of this species. The Batang Tarusan River is situated in the Western Sumatera; it is hydrologically characterized by a predictable monomodal flood pulse that regulates the environmental conditions for a variety of organisms and allows the migration of some fish species. Tor tambroides is a pelagic species whose eggs and larvae are produced in the headwaters and are taken downstream (Esa et al., 2008; Shrestha., 1990). In the years when the flood pulse is intense, the different inundated areas interconnect with each other, making the landscape that allows individuals from different side of rivers to mix before the waters are delivered to the lower parts of the rivers. This pattern of population mixing prevents genetic differentiation. The absence of genetic structure among populations and the interaction between their life cycle and natural flooding variations suggest that the Tor tambroides in the Batang Tarusan River form a single panmictic population (i.e., individuals of the same species grouped into geographically separated populations that experience some level of genetic interaction).

Genetic data from this study showed a little variability, corroborating the previous idea, did not gave support to the hypothesis of existence of discrete groups of Tor tambroides along the Batang Tarusan River, suggesting that the populations could be treated as a single genetic stock. Regarding fishery management, the Tor tambroides in the Batang tarusan River needs to be managed as a genetic unit.

\section{ACKNOWLEDGMENTS}

We would like to thank the support of Research Institute for Inland Fisheries staff for their help in the field work. Also, we thank the Research Institute for Inland Fisheries through DIPA 2012 for funding this work and the Laboratory of Molecular Ecology where part of the molecular analysis has been done. 


\section{REFERENCES}

Avise J.C., J. Arnold, R.M. Ball, E. Bermingham, T. Lamb, J.E. Neigel, C.A. Reeb \& N.C. Saunders. 1987. Intraspecific phylogeography: The mitochondrial DNA bridge between population genetics and systematics. J. Annu Rev Ecol Res. 18: 489-522.

Billington, N. \& P.D.N. Hebert. 1991. Mitochondrial DNA diversity of fishes and its implications for introductions. Can. J. Fish. Aquat. Sci. 48 (Suppl. 1), 80-94.

Birky, C.W., T. Maruyama \& P. Fuerst. 1983. An approach to population and evolutionary genetic theory for genes in mitochondria and chloroplast and some results. Genetics. 103, 513-527.

Esa, Y.B., S.S. Siraj, S.K. Daud, K.A.A. Rahim, J.R.R. Japning \& S.G. Tan. 2008. Mitochondrial DNA Diversity of Tor tambroides Valenciennes (Cyprinidae) from Five Natural Populations in Malaysia. Zoological Studies. 47(3): 360-367.

Excoffier, L., G. Laval, \& S. Schneider. 2005. Arlequin ver. 3.1: an integrated software package for population genetics data analysis. Evol. Bioinformatics. Online 1: 47-50.

Excoffier, L., P.E. Smouse \& J.M. Quattro. 1992. Analysis of molecular variance inferred from metric distances among DNA haplotypes: application to human mitochondrial DNA restriction data. Genetics. 131: 479-491.

Felsenstein, J. 1985. Confidence limits on phylogenies: an approach using bootstrap. Evolution. 39: 783-791.

Hall, T.A. 1999. BioEdit: a user-friendly biological sequence alignment editor and analysis program for Windows 95/98/NT. Nucleic Acids Sym. Ser. 41: 95-98.

Hurlbut, T. \& D. Clay. 1998. Morphometric and meristic differences between shallow- and deep-water populations of white hake (Urophycis tenuis) in the southern Gulf of St. Lawrence. Can. J. Fish Aquat. Sci. 55: 2274-2282.

Ihssen, P.E., H.E. Booke, J.M. Casselman, J.M. McGlade, N.R. Payne \& F.M. Utter. 1981. Stock identification: material and methods. Can. J. Fish Aquat. Sci. 38: 1838-1855.
Ingram, B.A., S. Sungan, G.J. Gooley, Y.S. Sim, D. Tinggi \& S.S. De Silva. 2005. Induced spawning, larval development and rearing of two indigenous Malaysian Mahseer, Tor tambroides dan Tor duoronensis. Aquat. Res. 36: 1001-1014.

Ivanova, N.V., T.S. Zemlak, R.H. Hanner \& P.D.N. Hebert. 2007. Universal primer cocktails for fish DNA barcoding. Molecular Ecology Notes 7: 544548.

Kimura, M. 1980. A simple method for estimating evolutionary rate of base substitutions through comparative studies of nucleotide sequences. $J$. Mol. Evol. 16: 111-120.

Meyer, A. 1993. Evolution of mitochondrial DNA in fishes. Elsevier, Amsterdam. 1-38 pp.

Nei, M. 1987. Molecular Evolutionary Genetics. Columbia University Press, New York.

Nei, M. \& F. Tajima, F. 1981. DNA polymorphism detectable by restriction endonucleases. Genetics. 97: 145-163.

$\mathrm{Ng}, \mathrm{C.K} .2004$. King of the rivers: mahseer in Malaysia and the region. Inter Sea Fishery (M). SDN BHD, Kuala Lumpur. $170 \mathrm{pp}$.

Nguyen, T.T.T, B. Ingram, S. Sungan, G. Gooley, S.Y. Sim, D. Tinggi \& S.S. DeSilva. 2006. Mitochondrial DNA diversity of broodstock of two indigenous Mahseer species, Tor tambroides and Tor dourenensis (Cyprinidae) cultured in Sarawak. Aquaculture. 253: 259-269.

Ovenden, J.R. 1990. Mitochondrial DNA and marine stock assessment: a review. Aust. J. Mar. Freshw. Res. 41, 835-853.

Shrestha, T.K. 1990. Rare fishes of Himalayan waters of Nepal. J. Fish Biol. 37, 213-216.

Tamura, K., J. Dudley, M. Nei \& S. Kumar. 2007. MEGA4: Molecular Evolutionary Genetics Analysis (MEGA) software version 4.0. Mol. Biol. Evol. 24: 1596-1599.

Thompson, J.D., T.J. Gibson, F. Plewniak, F. Jeanmougin \& D.J. Higgins. 1997. The clustal X windows interface: Flexible strategies for multiple sequences alignment aided by quality analysis tool. Nucleic Acid Res, 25 (24): 4876-4882. 